\title{
Visibility Of Invisible Home-Based Women Workers: A Recent Study Of Home-Based Women In Karachi
}

\author{
Muhammad Nademullah \\ \& \\ Nasreen Aslam Shah \\ Department of Social Work \\ University of Karachi
}

\begin{abstract}
This paper is based on a recent field research conducted in nine towns of Karachi which explored nine hundred home-based women workers' experiences and perceptions and documented the typology of the work accomplished by them. Working under harsh circumstances, caught in the cobweb of poverty and patriarchal forces, the low-paid work of these women forms a link between the walled enclosures of their homes and the economic transactions in the markets outside. The data collected from the home-based women workers, selected randomly, through questionnaires and personal narratives reveal that they do work within the walled spaces of their homes but their lives are neither bounded by space nor they live in isolation. On the contrary, they are well aware of the world outside and understand how forces of corruption and exploitation working under the aegis of capitalist economy play havoc in their lives. Their resolve to confront poverty, to challenge exploitative forces, to toil hard for a better life for their children, and to act as role models for other women, make them as visible partners of efforts geared to have a self-sustained Pakistan. This paper by deconstructing the myth of Pakistani women's existence as prisoners within their homes, presents a picture of women who through their visible economic contribution are making viable changes in the society. All this, thus transforms the home-based working women who have been consistently, though wrongly portrayed as 'invisible' into autonomous beings, visible to those who have an eye to see the reality. The paper also seeks to critically look at the norms of patriarchy, including the traditional codes of observing pardah in the context of women and gender in Pakistan. This paper also develops an argument showing how patriarchal traditions tend to hide all weaker segments of society- men and women, and makes them visible only when their services are required.
\end{abstract}

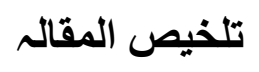

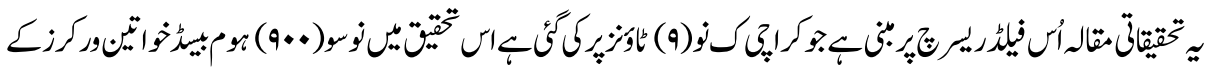

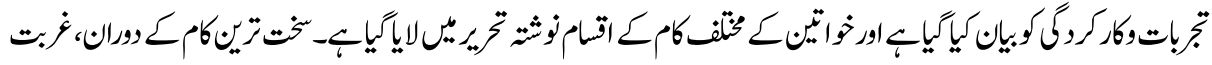

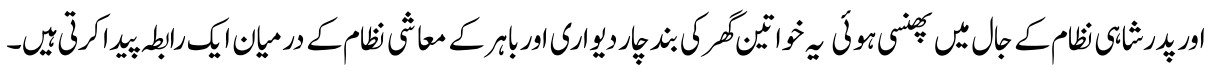

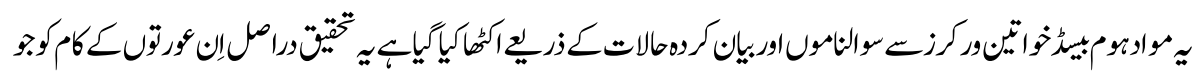




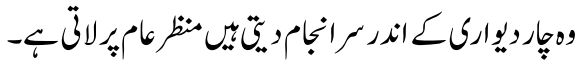

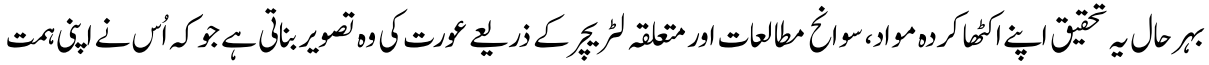

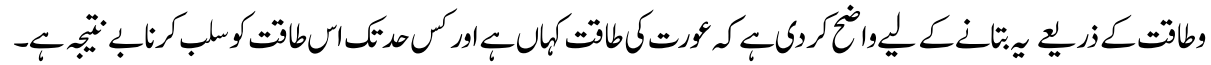

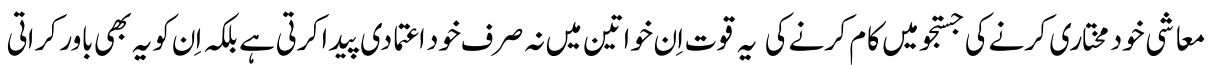

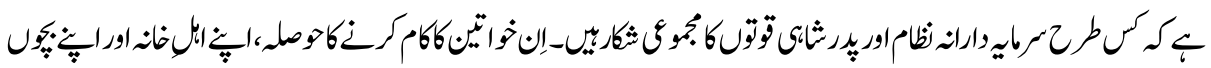

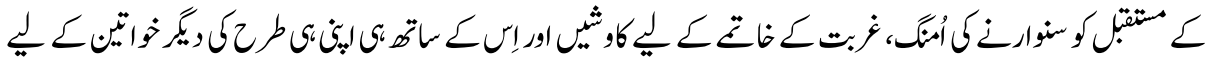

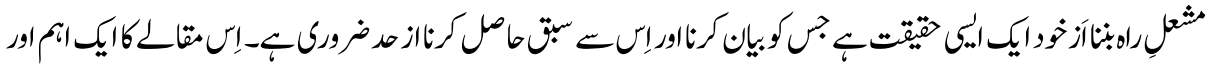

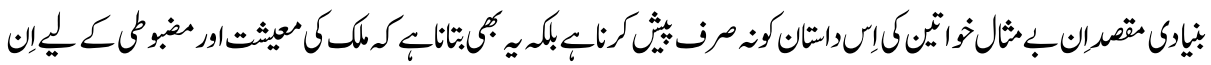

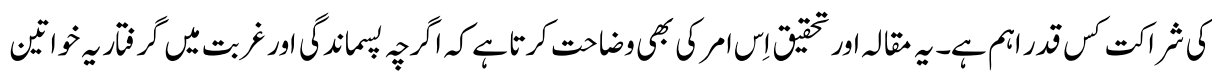

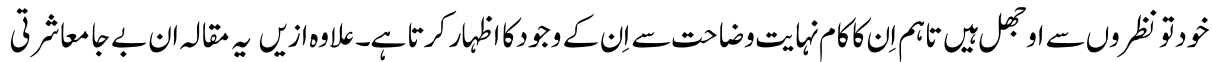

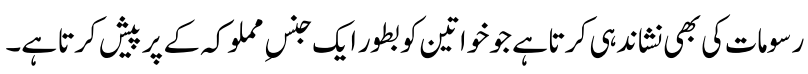

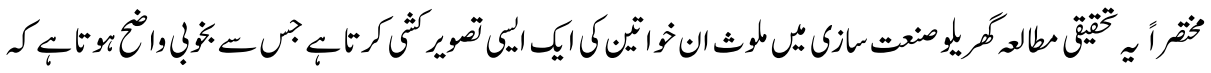

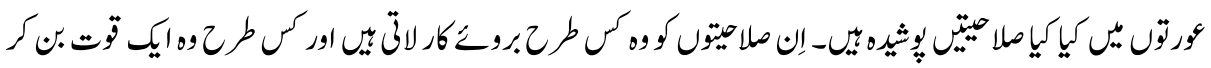

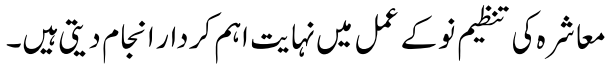

\section{Introduction}

It was the Quaid-e-Azam who struck at the very crux of South Asian Muslims' social, political and economic ailment and with great acumen and sagacity told his community:

'No nation can rise to the height of glory unless your women are side by side with you. We are victims of evil customs. It is a crime against humanity that our women are shut up within the four walls of the houses as prisoners. I do not mean that we should imitate the evils of the Western life. But let us try to raise the status of our women according to our own Islamic ideas and standards. There is no sanction anywhere for the deplorable conditions in which women have to live. You should take your women along with you as comrades in every sphere of life, avoiding the corrupt practices of Western society. You cannot expect a woman who is herself ignorant to bring up your children properly. The woman has the power to bring up children on right lines. Let us not throw away this asset.'

(Quaid-e-Azam Muhammad Ali Jinnah's speech at a meeting of the Muslim University Union, Aligarh, 10 March, 1944). 
These sane words are lost today. Instead of progress and development what happened to women is recorded in the Report of the Commission on the Status of Women in 1985 in these words that women are 'Bought and sold, beaten and mutilated, even killed with impunity and social approval, dispossessed and disinherited despite legal safeguard' (Mumtaz \& Shaheed,1987). Mumtaz and Shaheed clarifying women's position in Pakistan observe that 'depending on her geographical location, a Pakistani woman can find herself in tribal, feudal, or a self-effacing peasant toiling alongside her men folk; she can lead a highly cloistered life cut off from all decisions and information in the urban lower middle class ghettos of respectability or in the wide expanse of the nomadic regions, or she can be a central figure of authority in the limited circle of influential women in government and business circles'.

More than six decades have passed since the creation of Pakistan on August 14, 1947 and yet the nation is still discussing what should be the role of women in the country's development. Pakistan, in which approximately 95\% of the population is Muslim, was constitutionally declared an Islamic State by the Objective Resolution in 1949. ${ }^{1}$ This Resolution later became a substantive part of the present constitution of the country by an article $2 \mathrm{~A}$ in 1985 . $^{2}$ Constitutionally women are not discriminated as their legal equality with men is guaranteed. Article 25 of the Constitution of Pakistan lays down that all citizens are equal before law and are entitled to equal protection of law.

Pakistani society is complex in nature as one encounters dichotomy in its set up. Historically it is patriarchal in its nature and is controlled by a feudalistic order which is deeply entrenched in its everyday social behaviour. The society, primarily being male dominated, accords the status of secondary citizens to women. This lower status has significantly downgraded the role and status of women in all walks of life. The majority of Pakistani women live in the rural areas where they do hard work in the fields and are victims of poverty, illiteracy and poor health. Working conditions are harsh. Life in urban areas is not much different either.

The social system of the country is both authoritarian and patriarchal. This has led to the separation of public and private spheres of life to the exclusion of women from the economic marketplace and political decision making. Pakistani society at all its levels, urban and rural set up, is controlled by strong patriarchal norms. This patriarchal norm imposes strictly restraints women's mobility. This restriction functions in a highly complex manner and is not merely limited to female seclusion within the four walls of the homes. Interaction with men whom a woman cannot marry is strictly enforced in certain sections of the society creating 'separate worlds for men and women'(Papanek, 1971, p.519, 528). The process of Islamization that started during the early 80 s and which again is on the rise under the new threat of Talibinazation of the land has further strengthened the process of female segregation. It is against this backdrop that women's 
lives have to be monitored and their formal as well as informal labour force participation rate is to be measured. It is worth noticing that though these restrictions are primarily created for Muslim women, however, women belonging to other faiths, such as Christian and Hindu religion, are also affected by these.

As established by the findings of this current research, women remain engaged in income generating activities despite the commonly held assumption that it is a man's responsibility to provide for the needs of the family. This assumption, lasting through centuries of male fictional authority, has resulted in yet another myth - that respectable women remain contended with whatever their males bring back home. This notion of respectability (sharafat) and family honour (izzat) has created code of behaviour for women. While this code of behaviour or as Anita Weiss defines it as 'traditional norms of propriety' have not prevented women from working, have certainly 'prevented women and their families from admitting that they engage in such work'(Anita M, 1992). Weiss stresses the importance of the compatibility of pardah norms with women's economic activities. Her study shows that in the informal sector women do the same kind of smallscale manufacturing that men do in the markets, but women do it at home for low wages.

The age old patriarchal method of enforcing women's conformity to their 'traditional role' of housekeepers for their husbands and producers of their male progeny entails a never ending tale of physical abuse and emotional torture. Her failure to give birth to a son may cause a serious tension, threatening relationship with the husband and the inlaws (Rahman, 1995). Marriage is the key turning point in a person's life. In Muslim societies, however, marriage often turns into a gruesome life experience if the bride's virginity is suspected, if she has failed to bring with her enough dowry or if she insists on claiming her self identity. In view of these multiple threats and dangers most victims remain silent and the traumatic experiences are not divulged. As women seldom express their fears therefore their families, and quite often their own children can be insensitive to them(Anwar, 1996). Thus contrary to what the founding leaders' of Pakistan had envisioned the future of Pakistan, the country soon after 1948 experienced an urbanbased resurgence of politicized religion, the centre point of which continues to be a search for effective mechanism for holding down women under the control of men. It took almost sixteen years for Pakistan to acknowledge the principle of political equality of women and to explicitly recognize the State's responsibility 'to ensure full participation of women in all spheres of national life' (Article34 of 1973 Constitution of Pakistan).

The self-employed women whose life and work experience is presented in this paper are the dwellers of squatter settlements, slums and the katchi abadis. ${ }^{3}$ Located in the nine selected towns of Karachi, these make-shift colonies of human settlement stand as testimony to bad governance and mismanagement of human resources. Representing a 
variety of Pakistani cultures, the home-based women workers whom researchers met in the last several years narrated how poverty, deprivation, and discrimination play havoc in their lives and how prepared they are to challenge them, fight them and defeat them.

The statistical profile of self-employed women in Pakistan mostly remains unknown. The number is increasing as more and more women are entering into the field of home-based work. Factors that motivate and encourage them to decide are also changing. This makes the task of a researcher challenging. The escalating number of women workers, together with the ever-increasing physical spread of the area selected for the study, point out that more in-depth studies are needed.

Although historically women have always remained active generators of income, research regarding the gendered nature of economic development is very recent (Braunstein, 2007). Sociologists, anthropologists and development economists have recently produced some studies on the life and experiences of self-employed women. Such studies are very few regarding Pakistani women. Looking at the magnitude of the work undertaken by women at home and the increasing number of women involved in such undertakings, this paper attempts at presenting a holistic image of women and of their work.

The present study drawing upon field study conducted in the nine towns of Karachi with interviews of nine hundred home-based women workers covers a wide range of issues including the type of work done by them, their social and economic problems, and the possibility of some remedial measures for alleviating home-based workers' problems. The search for literature related to this theme showed that despite the great contribution of the home-based women workers towards building self reliance within their families and improving national economy, little is known about their lives and experiences. Unlike the neighbouring countries of the South Asian region, mainly India and Bangladesh, data regarding self-employed women in Pakistan is hard to find. This lack of information has hindered in many ways projects that could have been implemented for adding quality to their lives and the work they undertake.

The Pakistan economy, since its inception in 1947, is marked by uneven development. This uneven development or underdevelopment while deepening stratified social structures has also created gender imbalance. Women, being the most subordinated class irrespective of their socio-economic affiliations, are worst hit by this process of development. In addition to their traditional work within the family, women of the low income groups seek paid work to get 'little' money for their family's income. Shari Bhowmik and Renana Jhabwala presenting the profile of the self-employed women as 'the weakest, most exploited section of workers' as they 'earn less than a minimum wage and have no assets of their own' (Bhowmik \& Jhabwala, 1996) have identified the major 
issues that are not limited to the women they studied but indeed mirror the lives of the self-employed women in other regions also. In their everyday life these self-employed women confront formidable challenges as their "employment is insecure and often there is no work at all'. In addition to work related problems 'they have few rights within the family' (Bhowmik \& Jhabwala, 1996).

The first challenge confronting a researcher for undertaking a study about the homebased women workers is how to define them and their work. Field-observations and respondents' self-description show that they move from one category to the other without bothering how the researchers and the academics define their work. In this paper, therefore, the term home-based working woman, self-employed woman, and piece-rate woman worker are used making little variations in their conceptual understanding. To decide as to which of these terms is more applicable or best suited to describe and define women and the work they do one must listen to the voice of the women themselves. It is worth mentioning here that when researchers sought women's opinion regarding the category of work they fall into, they looked baffled and appeared little irritate. What concerns them and what is ground hard reality for them (and should be for us as well) is that they have decided to work and are engaged in gainful employment, in addition to their daily chores. Thus terms, they said in a matter-of-fact voice, are nothing but a mere past-time activity that has no end result but makes them and their work an object of laboratory dissection, benefiting the scholars and turning them into objects of study.

Hamza Alavi, a Marxist-Sociologist of Pakistani origin, assessing women's work in the context of their educational attainments, writes, 'In the case of lower middle class families we can identify a two-fold division. On the one hand there are families whose women are educated, sufficiently at least to hold down a 'respectable' job. On the other hand there are more traditional families whose women have not received a good education who therefore do not qualify for 'respectable' salaried jobs. In the latter cases women contribute to the family economy by taking in home-based work under a putting out system operated by entrepreneurs who are only too happy to exploit this extremely cheap source of labour'(Alavi, 1991).

This research study explores the problem of home-based and self-employed women's invisibility within the larger context of norms of female seclusion that are now more stressed upon subsequent to the spread of the so-called 'fundamentalist ideology' of Islam. Does the home-based work provide justification for strengthening female seclusion and restrictions on their mobility? The study also studies how the home-based women workers view themselves and their work. Do they look at themselves as being doubly exploited by their families - in their reproductive role and in their role as incomegenerators for the family's needs? Does their work and the income they acquire enhance their status? Do they feel liberated and empowered? Have they really exploded the myth 
of women's economic subordination? Pakistani women, as women of the so-called Third World, are depicted as passive, inactive and subordinated women with no voice of their own and no power to resist injustices and explore alternative options for themselves and their families. This portraiture of Pakistani women is outdated and is no longer applicable to all women. It must be noted here, that this study is not negating the presence of either forces of patriarchy and of the power of the obscurantist's; nor does this research denies the class stratification of the society which indeed is widening due to acute poverty. Thus the basic question this paper addresses is: How does self-employment work as a catalyst in changing the role of women in the tradition bound society of Pakistan? How do these women combine the two responsibilities-the role as the family caretaker and the role as family provider-and how does this combination change or does not change their attitude towards these two responsibilities and towards work? The over-arching question that indeed is a major problem in the path of women' development and the country's progress and which continues to emerge is regarding the meaning of work itself. Work in its popular usage and understanding is still the work that men do to earn money. What women do is to fill in their 'free time'. This societal attitude not only keeps women veiled but also puts their earnings under cover.

The study develops the argument that these women workers are not only victims of gender and socio-economic disparities but they also strengthen gender disparities by remaining bounded by space and by the nature of the work they do. What makes women decide to work within the four-walls of their home? Why women's work is under-valued and why their earnings are low? What factors are at work depriving self-employed women in particular and women in the informal sector of economy of legal protection and other benefits? What keeps them hidden? Although an attempt is made to find answers for these questions but the researcher must admit that finding answers is not easy for the researchers in the social science. A good research raises questions, thus making the issues visible.

The most important object of this study is to make the home-based women workers visible and to seek recognition and acceptance for their contribution towards the country's economic growth and national earnings. Women who participated in this study were involved simultaneously in their household work and in their income generating work. Both indeed, to use the feminist concept of women's work, help generate money. Work done by women, whatever might be its nature has been much debated in recent feminist scholarship. They strongly advocate that women's work spans community and industry and 'the social relations of work, its cognitive and affective domains, and its sexual divisions are structured around gender'(Maggie,1989, p.311). Another strong argument of feminist theory is that women's work must be seen in the context of the family economy. Anja K. Frank in her paper 'Key Feminist' concerns regarding core labour standards: Decent work and corporate social responsibility' observes that the 
'prevailing definition of 'work' is waged labour in a formally structured relation - a definition based upon a masculine ideal of 'work' (Frank, 2008). ${ }^{4}$ She further adds that in order to understand the concept of work what is 'equally important is that what is regarded as work is a result of both social and statistical definition which have a variety of meanings' (Maggie, 1989, p.16). The term 'women workers' also needs to be explained a little in view of the growing scholarship about the co-relation between women and work. An interesting argument is advanced by feminist theorists claiming that the working woman wage earner is 'likely to be more radical than the housewife. This is because women workers see the reality of wage differentials and therefore know that women's rights do not exist in practice' (Maggie, 1989, p. 313).

The most vicious drawback that halts women's forward movement in Pakistan is the social norm of pardah and segregation. In this heated debate the issue of women's seclusion and segregation has merged as the most significant topic. Restrictions on women's mobility has increased to such limits that it has become a mockery of human life. The practice of keeping women restricted to the world outside the home and to knowledge and information has not only crippled women and dwarfed their personalities but its consequences have become a dangerous problem for men as well. It is important here to look briefly at the Qur'anic injunction (S: 24: 30-31, The Qur'ān) regarding pardah:

And say to the believing women

That they should lower

Their gaze and guard

Their modesty; that they

Should not display their

Beauty and ornaments except

What (must ordinarily) appear

Thereof; that they should

Draw their [khumar] over

Their bosoms and not display

Their beauty except to. . .

The interpretation of this verse has virtually resulted in imprisoning women. Modernist scholars, however, give a different interpretation, an interpretation which reflects the humane spirit of Islam. Amina Wadud on the issue of veiling and segregation of women notes that the Qur'ān acknowledges the virtues of modesty, but not veiling and seclusion, which are culturally and economically determined demonstrations of modesty (Wadud, 1999). Contrary to these interpretations of the Qur'an regarding women and their seclusion what has come to influence and shape public opinion on this issue are directives issued by male authorities such as the world respected scholar Maulana Abul Ala Maududi. In his popular work, originally written in Urdu and later translated into English for wider circulation, Pardah and the Status of Women in Islam, Maududi, the founder of 
the political-religious party, the Jamāa't-i Islāmī, says that 'Though the veil has not been specified in the Qu'rān, it is Qur'ānic in spirit'(Maududi, 1972). Among the religious scholars whose commandments have transformed women's seclusion into male acts guaranteeing them high rewards in the next life, the foremost name is that of Maulana Ashraf Ali Thanawi (1864-1943), the author of the most popular text, the Bhishti Zewar. In his book Fatwa Ashrafiya, Thananwi not only upholds pardah but promotes it as a means of protecting the community from chaos. He writes that men who force their women into pardah will receive the highest reward in life hereafter(Thanwai, 1997).

Farida Shaheed, a Pakistani sociologist, examining pardah as an institution that controls and governs the lives of women in Pakistan explores its impact on women's access to economic resources and employment opportunities. She deplores the fact the impact of pardah is normally ignored in development-related research (Shaheed, 1989).

Another significant fact is that the Qur'an does not prevent women from earning money and having control over it: '...to men is allotted what they earn, and to women, what they earn; but ask Allah of His bounty for Allah has full knowledge of all things' (4:32, The Qur'an). Leila Ahmed discussing women's potential in the context of the Middle Eastern Muslim women notes that 'because Islamic law permits women to inherit and independently own property, women of the middle class often had property and engaged in various business activities, such as selling and buying real estate, renting out shops, and lending money at interest'(Ahmed, p.110). Ahmed also shows that 'women of all classes engaged in sewing, embroidery, and other forms of textile production' (Ahmed, 1992, p.112). This was not a mere leisure activity but as Ahmed observes 'it is clear that women could drive some income from textile work. Evidence from early nineteenthcentury Cairo shows that women were economically involved to a significant degree in cloth making, especially spinning and carding; this was in particular the case prior to encroachment of European markets and the importation of European goods. The women purchased the raw cotton or linen, processed it in their own homes, and resold it, or they engaged in a "putting out" system, in which traders bought the cotton or linen, distributed it to the spinners and carders, then collected it from them for a piece rate distribution for distribution to weavers working shops' (Ahmed, 1992, p.112). Regarding income of these women, Ahmed says that it was 'generally modest'. Citing cases from early 19th c. Cairo, Ahmed writes that women there 'could make a good living embroidering women's jackets and other luxury items for the wealthy. An exceptionally successful woman might even employ young girls at low wages to serve as apprentices' (Ahmed, 1992, p.112).

Sabiha Hafeez, a feminist sociologist, similarly observes that "According to Islamic law, women's right to her money, real estate or other properties is fully acknowledged. She has full right to buy, sell, mortgage or lease any or all her properties. Her share is completely hers, and no one can make any claim on it including her father and her 
husband. Her possessions before marriage do not transfer to her husband and she can even keep her maiden name' (Hafeez, 1980).

Despite research spread over the past several decades, women's economic role and their participation in increasing family income remains marginally recognized. Stephanie Barrientos and Naila Kabeer, feminist economists and development analysts, observe that 'women's earnings are often a crucial element in household survival, they are not 'secondary earners' as depicted in more traditional employment models, and they can accrue many advantages from their employment' (Barrientos \& Kabeer,2004).

In the western academic world Kate Millet and Shulamith Firestone are the strong advocates of the argument that 'gender distinctions structure every aspect of our lives by constituting the unquestioned framework in terms of which society views women and men'(Maggie, 1989, p. 106). These distinctions have set boundaries demarcating separate spheres for men and women to function. Society not only frowns at any attempt to cross these set lines but often punishes the 'wrong doers' - mostly women. Work in which contact with males cannot be avoided is associated with loss of respect and diminishes marriage prospects for single girls. Thus Pakistan's informal urban labour market is highly segregated, even for a Muslim country. The workers, street vendors, market sellers, carpenters, mechanics, and barbers are almost exclusively male. Women are confined to being domestic servants or home-based workers who stitch clothes, make lace, weave baskets, embroider, make food products and do similar other jobs.

'This tendency for men and women to be employed in different occupations is known as occupational segregation by sex' explains Debra Barbezat, (2003). This gendered nature of work and segregation is not limited to the traditional societies but as Richard Anker observes 'it is extensive in every region, at all economic levels, under all political systems, and in diverse religions, social, and cultural environments (Barbezat, 2003,p.177)'.

At the same time women doing work to earn money is not a new phenomenon in Pakistan. Clare Wilkinson-Weber reviews a long list of published material on women and work. In most of these books women's work is classified a "free-time" labour, and they are described as "helpers" of men (Wilkinson-Weber,2001,pp.91-103). She further writes that "in order to understand why women's work is ignored or downgraded, it is necessary to tackle the question of purdah. Does purdah prevent women from working, as it is often suggested?" Referring to Michelle Maskiell that we lack a fully historical understanding of purdah, she suggests that one should be "cautious of drawing essentialist conclusions about the impact of purdah upon employment" (Wilkinson-Weber,2001,p.98).

In most South Asian countries a large number of women in the urban areas are selfemployed, doing a variety of work. Slahuddin and Shamim in their study on Women in 
Urban Informal Sector which presents the case of Bangladeshi women found that almost all of them were poor and worked under stressful conditions at the lowest level of the trading hierarchy (Salahudin \& Shamim, 1992). Salahuddin and Shamim's description of the working conditions of similar women in Bangladesh fits well with respondents of this study. Yasmeen Mohiuddin, a sociologist from Pakistan and who now teaches in the West, recognizes that 'poverty is both a gender and class issue' in South Asia. Explaining this further she adds. 'Unequal gender relations (laws, rules, and norms) feminize poverty so that there are more poor women than there are poor men, their poverty is more severe, and they face greater hardship in lifting themselves and their children out of the poverty trap (Mohiuddin, 1997,p.178)'. Because of these unequal gender relations, Mohiuddin asserts 'poor women suffer more from capability deprivation than poor men. Poor women in South Asia have unequal and limited access to public service such as health and education, to productive resources such as credit, technology, land, markets, and wage employment, and governance decisions (even within the household) that affect their very existence' (Mohiuddin, p.169).

Work done by the self-employed women is unregulated and not only remains undervalued but in some cases even unrecognized and hidden away from public recognition as women's work. As the categories of work undertaken by women often include the traditional work done by housewives and therefore the work they do to earn money is also not recognized as 'real work'. Self-employed women basically are women who work to earn their livelihood. What differentiates them from other wage-earning and income generating workers is their choice of work place, i. e. their home premises. Therefore, it is of paramount importance to recognize at the very beginning that the selfemployed women do not operate in isolation. Indeed living in isolation or distanced from the others is a negative social behaviour in the South Asian society. From the perspective of market economy too, the self-employed women work under the same pressures as any other entrepreneurs do. However, the gender biases that are embedded in Pakistani society not only limit women's access to the world outside the home boundaries but it also decreases the acceptance level of women's work. Thus, women's work, irrespective of its nature, category, place of work, and the emoluments that it brings, has yet to be socially approved.

One great paradox here, similar to several other complex paradoxes governing women's lives in Pakistan, is that while the income earned by women is welcomed by the family, this welcoming attitude remains camouflaged, thereby forcing a major section of women and their families, including elderly women of the house, to deny that women are working to earn money. Anita Weiss is correct in saying that productive contributions of poorer Muslim women who 'are often physically veiled' also remain "veiled" in popular assessments and official documentation(Wiess,1992). Similar concerns are expressed by Yasmeen Mohiuddin regarding Pakistani women who 'are integral to Pakistan economy 
and are engaged extensively in the rural, urban informal sectors.' They also find it problematic that although women are in the mainstream of economic activity as far as their labour input is considered but not in terms of access to productive resources or support services. Mohiuddin draws a conclusion similar to that of Weiss and says that this paradox occurs 'because their economic activities are unnoticed, disregarded, or invisible' (Mohiuddin, 1997). Mohiuddin further clarifies that this invisibility is not caused by norms of veiling as 'the reality is that almost all poor women work, and have worked, in all cultures and for all time, irrespective of the norms of seclusion or veiling' (Mohiuddin, 1997p. 169).

In summation, it is strongly argued that it is highly important that home-based women's work should be recognized as income-generating work and not as their 'free-time activity'. Also, we must accept that the work women do is double of that men do as women combine income generation with their household work and with their biological function of reproduction. In this connection we look forward to changes in our deep-set social norms, inter-personal human relationships, use of male-dominated language, and more importantly in the governance of the country. If these changes do not occur women and particularly home-based women workers would remain hidden away and their contributions would continue to be usurped by the tyrannical social norms.

\section{End notes}

1. The ideology of Islam as the guiding principle of the new country was adopted by the first Constituent Assembly of Pakistan by a resolution known as the 'Objective Resolution' passed in the year 1949 which declared that ultimate sovereignty belongs to Allah alone. For details see Objective Resolution and its Impact on Pakistan's Constitution and Law by Tanzilur Rahman (1996), Royal book Company, Karachi.

2. Article 2A lays declares: 'The principles and provisions set out in the 'Objective Resolution' reproduced in the Annex are hereby made substantive part of the constitution'.

3. For a definition of these different terms see Census and Socio-Demographic Survey of Mustafabad- A Squatter Settlement of Karachi by Arif Ghayur and Qamar Iqbal (1992), Karachi: Population Studies Centre, University of Karachi. Katchi Abadis literally means unauthorized settlements. However this term is used interchangeably with squatter settlements. The Environment and Urban Affairs Division of the Federal Ministry of Housing and Works, Government of Pakistan, created a separate administrative unit called the Katchi Abadi Cell to look after the needs of these settlements. 
4. .Also see The Self-Employed Women in Pakistan: A Case Study of the SelfEmployed Women of Urban Informal Sector in Karachi. Karachi: Pakistan Association for Women's Studies \& NEWS.

\section{References}

Ahmed, Leila (1992) Women and Gender in Islam: Historical Roots of a Modern Debate. New Havens: Yale University Press, p.1.

Alavi, H. (1991) "Pakistani women in a Changing Society" In Hastings Donnan/Pnina Werbner (eds.), Economy and Culture in Pakistan: Migrants and Cities in a Muslim Society, p. 129.

Anita M. Weiss (1992) Walls Within Walls, Life Histories of Working Women in the Old City of Lahore, Boulder, Westview Press, p.74.

Anwar. Unaiza Niaz (1996) 'Women and Mental Health-Understanding Women in Distress', in Pakistan Journal of Women's Studies; Alam-e-Niswan, 3 (1), pp. 87 91.

Barbezat, Debra (2003) 'Occupational Segregation around the World' in Katerine S. Moe (ed.) Women, Family, and Work: Writings on the Economic of Gender, Blackwell Publishing, p. 177.

Bhowmik, Sharit \& Renana Jhabwala (1996) 'Rural Women Manage their own Producer Co-operatives: Self-Employed Women's Association (SEWA)/Banaskantha Women's Association in Carr, Marilyn, Martha Chen \& Renana Jhabwala (ed.) Speaking Out-Women's Economic Empowerment in South Asia. New Delhi, Vistaar Publications. P.105.

Braunstein, Elissa (2007) 'The Efficiency of Gender Equity in Economic Growth: Neoclassical and Feminist Approaches'. The International Working Group on Gender, Macroeconomics, and International Economics, Working Paper Series www.genderandmacro.org.

Frank, Anja K. (2008) 'Key feminist concerns regarding core labor standards, decent work and corporate social responsibility', WIDE Network, Belgium, (www.widenetwork.org), p. 16 Also see Ayub, Nasreen (1994) The Self-Employed Women in Pakistan: A Case Study of the Self-Employed Women of Urban Informal Sector in Karachi, Karachi, Pakistan Association for Women's Studies \& NEWS, Karachi. 
Hafeez, Sabiha (1980) 'Women and Employment in Islam' in Selected Papers, The National Conference of Muslim Women. Women's Division, Government of Pakistan.

Maggie Humm (1989) The Dictionary of Feminist Theory, London, Prentice Hall, p. 311.

Maududi, 'Abul 'Ala (1972) Pardah: Shara'ī aur ijtimā'i nuqtah ye nigāh sē [Pardah: From the Religious and Social Perspective] Pathankot: Maktabāh jamā'at islāmī. Also, Pardah and the Status of Women in Islam, translated and edited by alAsh'arīm, Lahore, Islamic Publications.

Mohiuddin, Yasmeen Niaz (2007) "Health and Poverty: South Asia" in Encyclopaedia of Women and Islamic Culture, vol. 3, p. 178.

Mohiuddin, Yasmeen Niaz (1997) "Gender Inequality in the Pakistan Labor Market: Myth and Reality" In Rives, Janet M. \& Mahmood Yousefi (ed.) Economic Dimensions of Gender Inequality, Westport: Connecticut: Praeger.

Mumtaz, Khawar \& Shaheed, Farida (1987) Women of Pakistan: Two Steps Forward, One Step Backward? Lahore: Vanguard Books, p. 21.

Papanek, H. (1971) Purdah in Pakistan: Seclusion and modern occupations for women, in Journal of Marriage and the family, 33, 3: 519, 528.

Rahman. Shakila A. (1995) 'Maternal Mortality, Maternal Health Care and Culture' Pakistan Journal of Women's Studies: Alam-e-Niswan, 2 (1: 107-119; Interviews of the women patients by the author in the Gynecology Ward, Civil Hospital, Karachi, and with women devotees at the shrines in Karachi, July-August 1999.

Salahuddin, Khaleda \& Ishrat Shamim (1992) Women in Urban Informal Sector: Employment Pattern Activity, Types and Problems, Dhaka, Women for Women.

Shaheed, Farida (1989) "Purdah and Poverty in Pakistan", in Haleh Afshar and Bina Agarwal (ed.) Women, Poverty and Ideology in Asia: Contradictory Pressures, Uneasy Resolutions, Macmillan Press, pp. 17-42.

Thanawi, Maulana Ashraf Ali (1997) Fatawa Ashrafiya (Kamil), Karachi, Saeed Company.

Wadud, Amina (1999) Qur'ān and Woman, Reading the Sacred Text from a Woman's Perspective, New York, Oxford University Press, pp. ix-xxii. 
Wilkinson-Weber \& Clare M. (2001) “Gender, Handicrafts, and Development in Pakistan: A Critical Review", in Pakistan Journal of Women's Studies: Alam-eNiswan, 1\&2, pp. 91-103, 98.

Weiss, Anita M. (1992) Walls Within Walls, Life Histories of Working Women in the Old City of Lahore, Boulder: Westview Press. p. 73.

Muhammad Nadeemullah is a Ph.D scholar at the Department of Social Work, University of Karachi.

Nasreen Aslam Shah, Ph.D is Professor in the Department of Social Work and Director of the Centre of Excellence for Women's Studies, University of Karachi. 